\title{
Bur open Reduction in inequality in antenatal- care use and persistence of inequality in skilled birth attendance in the Philippines from 1993 to 2008
}

\author{
Honey Faith Molina, ${ }^{1}$ Keiko Nakamura, ${ }^{1}$ Masashi Kizuki, ${ }^{2}$ Kaoruko Seino ${ }^{1}$
}

To cite: Molina HF, Nakamura K, Kizuki M, et al. Reduction in inequality in antenatal-care use and persistence of inequality in skilled birth attendance in the Philippines from 1993 to 2008. BMJ Open 2013;3: e002507. doi:10.1136/ bmjopen-2012-002507

- Prepublication history for this paper is available online. To view these files please visit the journal online (http://dx.doi.org/10.1136/ bmjopen-2012-002507).

Received 17 December 2012 Revised 4 April 2013 Accepted 29 April 2013

This final article is available for use under the terms of the Creative Commons Attribution Non-Commercial 2.0 Licence; see http://bmjopen.bmj.com

\section{ABSTRACT}

Objective: To assess changes in the inequalities associated with maternal healthcare use according to economic status in the Philippines.

Design: An analysis of four population-based data sets that were conducted between 1993 and 2008.

Setting: Philippines.

Participants: Women aged 15-49 years who had a live-birth within 1 year in 1993 ( $n=1707), 1998$ $(n=1513), 2003(n=1325)$ and $2008(n=1209)$.

Outcomes: At least four visits of antenatal care, skilled birth attendance and delivery in a medical facility.

Results: The adjusted OR for antenatal-care use when comparing the highest wealth-index quintile with the lowest quintile declined from 1993 to 2008: 3.43 (95\% $\mathrm{Cl} 2.22$ to 5.28$)$ to 2.87 (95\% Cl 1.31 to 6.29$)$. On the other hand, the adjusted OR for the other two outcome indicators by the wealth index widened from 1993 to 2008: $9.92(95 \% \mathrm{Cl} 5.98$ to 16.43$)$ to $15.53(95 \% \mathrm{Cl}$ 6.90 to 34.94 ) for skilled birth attendance and 7.74 (95\% Cl 4.22 to 14.21$)$ to 16.00 (95\% Cl 7.99 to 32.02$)$ for delivery in a medical facility. The concentration indices for maternal health utilisation in 1993 and 2008 were 0.19 and 0.09 for antenatal care; 0.26 and 0.24 for skilled birth attendance and 0.41 and 0.35 for delivery in a medical facility.

Conclusions: Over a 16-year period, gradients in antenatal-care use decreased and the high level of inequalities in skilled birth attendance and delivery in a medical facility persisted. The results showed a disproportionate use of institutional care at birth among disadvantaged Filipino women.

${ }^{1}$ International Health Section, Division of Public Health, Graduate School of Tokyo Medical and Dental University, Tokyo, Japan ${ }^{2}$ Health Promotion Section, Division of Public Health, Graduate School of Tokyo Medical and Dental University, Tokyo, Japan

Correspondence to Dr Keiko Nakamura; nakamura.ith@tmd.ac.jp

\section{INTRODUCTION}

Globally, there is increasing concern regarding inequities in maternal health, especially in developing countries. ${ }^{1}$ The slow pace of reduction in maternal death rates despite cost-effective solutions has urged the international community to look beyond accomplishing national targets and to begin addressing wide disparities in women's health. ${ }^{2}$

\section{ARTICLE SUMMARY}

Article focus

- Assessing the changes in the inequalities associated with maternal healthcare use according to economic status in the Philippines.

Key messages

- The study showed a reduction in the inequality of antenatal-care use through time, suggesting a substantial coverage of women in the lowest quintile.

- However, inequality was shown to persist in skilled birth attendance and delivery in medical facilities, indicating minimal professional delivery care among disadvantaged women despite health system-wide efforts and improvements in the sociodemographic profile of the population.

- The results call for equity-oriented research and policies to close the wide gap in skilled care at birth in the Philippines and to determine the success factors in the reduction of inequality in antenatal-care use.

Strengths and limitations of this study

- This is the first study of long-term trends in inequalities in the utilisation of critical maternal health interventions using four comparable, nationally representative Demographic Health Survey (DHS) data sets commonly used as data sources in the literature.

- Comparability of the different survey years was achieved by selecting only the women who had live-births within 1 year.

- The DHS wealth index was used to represent changes in socioeconomic inequalities through time.

The key to realising equity in maternal health is the achievement of equity in key maternal health coverage, such as antenatal care (ANC) and skilled birth attendance (SBA). A previous study indicated the greatest inequity in SBA coverage followed by ANC of more than four visits. ${ }^{3}$ Wide inequalities in these interventions have hindered the 
reduction by 0.75 of maternal mortality ratio from 1990 to 2015 . $^{4-6}$

The Philippines has made efforts to improve women's health as mandated in its constitution and as a signatory to several women's international conventions including the Millennium Development Goals (MDG). National laws passed include the Magna Carta of Women (RA 9710), Maternity Benefits in Favor of Women Workers in the Private Sector (RA 7322) and Maternal Package for Normal Spontaneous Vaginal Delivery of the Philippine Health Insurance Corporation (PhilHealth). Starting 1995, the Philippine government has also implemented a number of maternal health programmes, including two Women's Health and Safe Motherhood Projects. Health system reforms to reduce maternal and neonatal mortality were also spearheaded through the Department of Health Administrative Order No. 20080029 resulting in the Integrated Maternal, Neonatal and Child Health and Nutrition Strategy (MNCHN). Specific reproductive health indicators of MNCHN to be met in 2010 include (1) an increase in modern contraceptive prevalence rate to $60 \%,(2)$ an increase in the proportion of pregnant women having at least four ANC visits to $80 \%$ and (3) an increase in SBA and facility-based births to $80 \%$.

There is, however, uncertainty regarding whether and how these maternal health policies and programmes have substantially reduced gaps in the use of key maternal interventions among women from varying socioeconomic backgrounds through time. The Philippines is currently off track and slow in achieving MDG-5. In 2010, the estimated maternal mortality ratio was 99/100 000 live-births, compared with the goal of $52 / 100000$ live-births in $2015 .{ }^{8}$ This slow achievement of national targets indicates wide economic and regional inequalities in maternal and child health services. ${ }^{9}$ The objective of this study was to assess the changes in inequalities in ANC, SBA and delivery in a medical facility (MEDFAC) in the Philippines between 1993 and 2008 according to woman's residence, woman's education, partner's education, wealth index, woman's age and birth order.

\section{DATA AND METHODS}

\section{Data source}

This study was performed using data from the Philippine Demographic and Health Survey (PDHS) conducted for the periods of 1993, 1998, 2003 and 2008. All were nationally representative household surveys overseen by the National Statistics Office and National Steering Committee with financial and technical support from the USA Agency for International Development. ${ }^{10}$ PDHS gathers detailed information on population, health and nutrition to assist in the country's monitoring and impact evaluation. It ensures comparability across countries and time by developing standard model questionnaires, extensive survey procedures, interviewer training and data-processing guidelines. ${ }^{11} 12$

The 1993 and 1998 PDHS employed a two-stage sample design, representing 14 and 16 regions, respectively. A sample of 13700 households (response rate: 99.2\%) was randomly selected from 750 primary sampling units (PSUs) for 1993 and a sample of 13708 households (response rate: 98.7\%) was randomly selected from 755 PSUs for 1998. The 2003 and 2008 PDHS followed a stratified three-stage cluster sample design representing 17 regions. A sample of 13914 households (response rate: 99.1\%) was randomly selected from 819 PSUs for 2003 and a sample of 13764 households (response rate: 99.3\%) was randomly selected from 794 PSUs for 2008. Detailed descriptions of the study design and methods of data collection are accessible online in household survey reports. ${ }^{13-16}$

\section{Subjects}

The numbers of women interviewed were as follows: 1993, $\mathrm{n}=15$ 029; 1998, $\mathrm{n}=13$ 983; 2003, $\mathrm{n}=13633$ and $2008, \mathrm{n}=13594$. The average response rate was $98 \%$. The participants we included in the analysis were women aged 15-49 years who had a live-birth within 1 year, resulting in final sample sizes of 1707 in 1993, 1513 in 1998, 1325 in 2003 and 1209 in 2008.

\section{Study variables}

Three dependent variables were measured in the present study: (1) at least four antenatal consultations; (2) assistance by professional health personnel during delivery-either a doctor, nurse or midwife, excluding traditional birth attendants (hilot), relatives or friends, and (3) whether the birth occurred at home or in MEDFAC (public or private).

The Demographic and Health Survey (DHS) wealth index is defined as a composite measure of a household's relative economic status by using the data in the DHS. It is calculated by using data on a household's ownership of selected assets such as a television or car, persons per sleeping room, ownership of agricultural land, domestic servant and other country-specific items. ${ }^{17}$ The asset quintile was derived from this DHS wealth index score of women who had a live-birth within 1 year categorised into lowest, second, middle, fourth and highest in the respective survey years.

Other independent variables were type of residence (urban or rural), woman's age $(<20,20-29,30-39, \geq 40)$, birth order $(1,2,3, \geq 4)$ and educational level of the woman and her partner (none, primary, secondary, higher).

\section{Ethical review}

As protocols for all demographic health household surveys, the four PDHS were submitted for ethical reviews to the ICF Institutional Review Board (Calverton, Maryland, USA) and an institutional review board or 
ethics review panel in the Philippines for approving research studies on human subjects. ${ }^{18}$

\section{Statistical analysis}

Changes in the sociodemographic profile and use of ANC, SBA and MEDFAC of the population were analysed from household survey data in 1993, 1998, 2003 and 2008. Tests for trends were performed using the Mantel-Haenszel linear-by-linear association $\chi^{2}$ test. Crude and adjusted ORs between each dependent variable and all of the independent variables were assessed by multivariate logistic regression analysis. Complex household survey design was taken into account in all analyses using a sampling weight. All the missing data were excluded in the analysis. All analyses were performed using StataMP V.11 Statistical Software (Stata Corp., College Station, Texas, USA).

Inequalities of each outcome variable according to the wealth index were estimated using the concentration index. It is defined as twice the area between the concentration curve and the line of equality (the $45^{\circ}$ line) and was used to determine the magnitude of inequality. A concentration index of 0 indicates perfect equality. A measure of 1 (or -1 ) indicates perfect inequality. ${ }^{19} 20$

\section{RESULTS}

There were changes in the sociodemographic profile of the population from 1993 to 2008 (table 1). The percentage of women with secondary and higher education increased during this period from $58.7 \%$ in 1993 to $74.6 \%$ in 2008. A corresponding increase was also observed in the percentage of partners who finished secondary and higher education from $57.4 \%$ in 1993 to $70.7 \%$ in 2008 . The percentage of women with four or more children declined from $39.9 \%$ in 1993 to $31.7 \%$ in 2008 .

Figure 1 shows that the utilisation of ANC and MEDFAC increased from $53.4 \%$ in 1993 to $74.8 \%$ in 2008 and from $30.7 \%$ in 1993 to $46.3 \%$ in 2008 , respectively. However, there is a limited change in utilisation of SBA from $55.5 \%$ in 1993 to $63.3 \%$ in 2008 .

As shown in table 2, from 1993 to 2008, the rates of utilisation of ANC, SBA and MEDFAC were higher for women who were educated, better off, resided in an urban area and those with educated partners than among their poorer and less educated counterparts. There was a decline in the OR of women in the highest wealth quintile compared with the lowest in ANC from 1993 to 2008. The adjusted OR for antenatal-care use when comparing the highest wealth-index quintile with the lowest quintile declined from 1993 to 2008: 3.43 (95\% CI 2.22 to 5.28 ) to 2.87 (95\% CI 1.31 to 6.29 ). On the other hand, the adjusted OR for the other two outcome indicators by the wealth index widened from 1993 to 2008: 9.92 (95\% CI 5.98 to 16.43 ) to 15.53 (95\% CI 6.90 to 34.94) for SBA and 7.74 (95\% CI 4.22 to 14.21 ) to 16.00 (95\% CI 7.99 to 32.02) for delivery in MEDFAC.
Table 1 Sociodemographic characteristics and childbirth history of women aged 15-49 years, per survey year, Philippines, 1993-2008

\begin{tabular}{|c|c|c|c|c|}
\hline Indicator & $\begin{array}{l}1993 \\
\mathrm{n}=1707 \\
(\%)\end{array}$ & $\begin{array}{l}1998 \\
n=1513 \\
(\%)\end{array}$ & $\begin{array}{l}2003 \\
n=1325 \\
(\%)\end{array}$ & $\begin{array}{l}2008 \\
n=1209 \\
(\%)\end{array}$ \\
\hline \multicolumn{5}{|l|}{ Residence } \\
\hline Urban & 48.8 & 46.3 & 50.0 & 46.9 \\
\hline Rural & 51.2 & 53.7 & 50.0 & 53.1 \\
\hline \multicolumn{5}{|c|}{ Woman's education } \\
\hline None & 2.3 & 1.8 & 1.9 & 1.2 \\
\hline Primary & 39.0 & 29.9 & 27.8 & 24.2 \\
\hline Secondary & 37.4 & 39.7 & 42.5 & 50.3 \\
\hline Higher & 21.3 & 28.6 & 27.8 & 24.3 \\
\hline \multicolumn{5}{|c|}{ Partner's education } \\
\hline None & 1.9 & 1.6 & 2.0 & 1.9 \\
\hline Primary & 40.8 & 33.4 & 31.8 & 27.5 \\
\hline Secondary & 37.3 & 36.7 & 40.1 & 45.0 \\
\hline Higher & 20.1 & 28.3 & 26.1 & 25.7 \\
\hline \multicolumn{5}{|l|}{ Wealth index } \\
\hline Lowest & 20.2 & 20.0 & 20.0 & 20.0 \\
\hline Second & 19.8 & 20.0 & 20.1 & 20.0 \\
\hline Middle & 20.0 & 20.0 & 20.0 & 20.1 \\
\hline Fourth & 20.0 & 20.1 & 19.9 & 20.1 \\
\hline Highest & 20.0 & 19.9 & 20.0 & 19.8 \\
\hline \multicolumn{5}{|l|}{ Woman's age } \\
\hline$<20$ & 5.6 & 6.1 & 7.2 & 8.2 \\
\hline $20-29$ & 53.7 & 53.7 & 53.3 & 53.5 \\
\hline $30-39$ & 35.6 & 35.1 & 34.4 & 32.5 \\
\hline$\geq 40$ & 5.2 & 5.1 & 5.1 & 5.8 \\
\hline \multicolumn{5}{|l|}{ Birth order } \\
\hline 1 & 22.6 & 24.5 & 27.7 & 28.5 \\
\hline 2 & 20.7 & 21.1 & 23.6 & 24.6 \\
\hline 3 & 16.8 & 19.6 & 15.5 & 15.2 \\
\hline$\geq 4$ & 39.9 & 34.8 & 33.2 & 31.7 \\
\hline
\end{tabular}

Figure 2 shows that there was a marked reduction in inequality of ANC from 1993 to 2008. Although gradients of its use among women with no education and women with higher education widened from 1993 to 2008, the gradients of ANC use among women with primary education and women with higher education as their highest educational attainment decreased from a difference of $40.4 \%$ point in 1993 to $31.6 \%$ point in 2008. A marked reduction was seen among women in

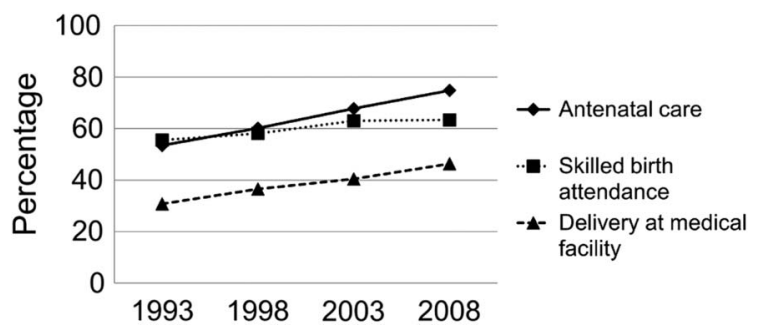

Figure 1 Total percentage of antenatal-care use, skilled birth attendance and delivery in a medical facility, 1993-2008. 
Table 2 Adjusted ORs of the association between wealth index and sociodemographic characteristics and antenatal care, skilled birth attendance or delivery in medical facility of women age 15-49 years, Philippines, 1993 ( $n=1707$ ), 1998 ( $n=1513$ ), 2003 $(n=1325), 2008$ ( $n=1209)$

\begin{tabular}{|c|c|c|c|c|c|c|c|c|c|c|c|c|c|c|c|c|c|c|c|c|c|c|c|c|}
\hline \multirow[b]{3}{*}{ Indicator } & \multicolumn{8}{|c|}{ Antenatal care } & \multicolumn{8}{|c|}{ Skilled birth attendance } & \multicolumn{8}{|c|}{ Delivery at medical facility } \\
\hline & \multicolumn{2}{|c|}{1993} & \multicolumn{2}{|l|}{1998} & \multicolumn{2}{|l|}{2003} & \multicolumn{2}{|l|}{2008} & \multicolumn{2}{|c|}{1993} & \multicolumn{2}{|l|}{1998} & \multicolumn{2}{|l|}{2003} & \multicolumn{2}{|l|}{2008} & \multicolumn{2}{|c|}{1993} & \multicolumn{2}{|l|}{1998} & \multicolumn{2}{|l|}{2003} & \multicolumn{2}{|l|}{2008} \\
\hline & OR & $\begin{array}{l}95 \% \\
\mathrm{Cl}\end{array}$ & OR & $\begin{array}{l}95 \% \\
\mathrm{Cl}\end{array}$ & OR & $95 \% \mathrm{Cl}$ & OR & $\begin{array}{l}95 \% \\
\mathrm{Cl}\end{array}$ & OR & $95 \% \mathrm{Cl}$ & OR & $95 \% \mathrm{Cl}$ & OR & $95 \% \mathrm{Cl}$ & OR & $95 \% \mathrm{Cl}$ & OR & $95 \% \mathrm{Cl}$ & OR & $95 \% \mathrm{Cl}$ & OR & $95 \% \mathrm{Cl}$ & OR & $95 \% \mathrm{Cl}$ \\
\hline \multicolumn{25}{|l|}{ Residence } \\
\hline Urban & $1.29^{*}$ & $\begin{array}{l}1.02 \text { to } \\
1.62\end{array}$ & $1.44^{* *}$ & $\begin{array}{l}1.08 \text { to } \\
1.93\end{array}$ & $1.70^{\star \star \star}$ & $\begin{array}{l}1.26 \text { to } \\
2.28\end{array}$ & 0.99 & $\begin{array}{l}0.71 \text { to } \\
1.38\end{array}$ & $2.59^{\star \star \star}$ & $\begin{array}{l}2.03 \text { to } \\
3.31\end{array}$ & $3.08^{* * *}$ & $\begin{array}{l}2.27 \text { to } \\
4.18\end{array}$ & $3.21^{\star \star \star}$ & $\begin{array}{l}2.37 \text { to } \\
4.34\end{array}$ & $2.11^{\star \star \star \star}$ & $\begin{array}{l}1.52 \text { to } \\
2.93\end{array}$ & $3.12^{\star \star \star}$ & $\begin{array}{l}2.35 \text { to } \\
4.12\end{array}$ & $2.43^{\star \star \star}$ & $\begin{array}{l}1.77 \text { to } \\
3.35\end{array}$ & $1.90^{\star \star \star}$ & $\begin{array}{l}1.41 \text { to } \\
2.56\end{array}$ & $1.47^{\star *}$ & $\begin{array}{l}1.07 \text { to } \\
2.02\end{array}$ \\
\hline $\begin{array}{l}\text { Rural } \\
\text { (reference) }\end{array}$ & 1.00 & & 1.00 & & 1.00 & & 1.00 & & 1.00 & & 1.00 & & 1.00 & & 1.00 & & 1.00 & & 1.00 & & 1.00 & & 1.00 & \\
\hline \multicolumn{25}{|c|}{ Woman's education } \\
\hline None & 0.58 & $\begin{array}{l}0.27 \text { to } \\
1.26\end{array}$ & 0.55 & $\begin{array}{l}0.21 \text { to } \\
1.45\end{array}$ & $0.25^{\star \star}$ & $\begin{array}{l}0.09 \text { to } \\
0.71\end{array}$ & $0.08^{\star \star \star}$ & $\begin{array}{l}0.02 \text { to } \\
0.36\end{array}$ & $0.17^{\star \star}$ & $\begin{array}{l}0.05 \text { to } \\
0.65\end{array}$ & 0.70 & $\begin{array}{l}0.21 \text { to } \\
2.39\end{array}$ & $0.22^{\star *}$ & $\begin{array}{l}0.08 \text { to } \\
0.66\end{array}$ & 0.66 & $\begin{array}{l}0.14 \text { to } \\
3.21\end{array}$ & 0.17 & $\begin{array}{l}0.02 \text { to } \\
1.94\end{array}$ & 0.48 & $\begin{array}{l}0.11 \text { to } \\
2.00\end{array}$ & $0.09^{*}$ & $\begin{array}{l}0.01 \text { to } \\
1.01\end{array}$ & 0.82 & $\begin{array}{l}0.09 \text { to } \\
7.51\end{array}$ \\
\hline Primary & $0.54^{\star \star}$ & $\begin{array}{l}0.37 \text { to } \\
0.79\end{array}$ & $0.46^{* \star *}$ & $\begin{array}{l}0.29 \text { to } \\
0.74\end{array}$ & $0.53^{\star \star}$ & $\begin{array}{l}0.34 \text { to } \\
0.85\end{array}$ & $0.38^{\star \star \star}$ & $\begin{array}{l}0.21 \text { to } \\
0.68\end{array}$ & $0.43^{* \star \star}$ & $\begin{array}{l}0.27 \text { to } \\
0.67\end{array}$ & 0.67 & $\begin{array}{l}0.39 \text { to } \\
1.12\end{array}$ & $0.48^{\star *}$ & $\begin{array}{l}0.30 \text { to } \\
0.78\end{array}$ & 0.69 & $\begin{array}{l}0.40 \text { to } \\
1.19\end{array}$ & $0.58^{\star \star}$ & $\begin{array}{l}0.38 \text { to } \\
0.88\end{array}$ & $0.52^{\star *}$ & $\begin{array}{l}0.31 \text { to } \\
0.86\end{array}$ & $0.44^{\star \star \star}$ & $\begin{array}{l}0.28 \text { to } \\
0.70\end{array}$ & 0.60 & $\begin{array}{l}0.35 \text { to } \\
1.03\end{array}$ \\
\hline Secondary & $0.67^{\star}$ & $\begin{array}{l}0.47 \text { to } \\
0.95\end{array}$ & $0.65^{\star}$ & $\begin{array}{l}0.44 \text { to } \\
0.97\end{array}$ & 0.69 & $\begin{array}{l}0.46 \text { to } \\
1.03\end{array}$ & $0.59^{\star *}$ & $\begin{array}{l}0.36 \text { to } \\
0.96\end{array}$ & $0.58^{\star \star}$ & $\begin{array}{l}0.38 \text { to } \\
0.88\end{array}$ & 0.86 & $\begin{array}{l}0.56 \text { to } \\
1.34\end{array}$ & 0.57 & $\begin{array}{l}0.37 \text { to } \\
0.89\end{array}$ & 0.89 & $0.56,1.41$ & $0.59^{\star *}$ & $\begin{array}{l}0.41 \text { to } \\
0.84\end{array}$ & $0.54^{\star \star \star}$ & $\begin{array}{l}0.37 \text { to } \\
0.78\end{array}$ & $0.49^{\star \star *}$ & $\begin{array}{l}0.34 \text { to } \\
0.70\end{array}$ & 0.77 & $\begin{array}{l}0.53 \text { to } \\
1.13\end{array}$ \\
\hline $\begin{array}{l}\text { Higher } \\
\text { (reference) }\end{array}$ & 1.00 & & 1.00 & & 1.00 & & 1.00 & & 1.00 & & 1.00 & & 1.00 & & 1.00 & & 1.00 & & 1.00 & & 1.00 & & 1.00 & \\
\hline \multicolumn{25}{|c|}{ Partner's education } \\
\hline None & $0.39^{*}$ & $\begin{array}{l}0.16 \text { to } \\
0.94\end{array}$ & $0.30^{\star}$ & $\begin{array}{l}0.10 \text { to } \\
0.85\end{array}$ & 0.41 & $\begin{array}{l}0.16 \text { to } \\
1.05\end{array}$ & 0.55 & $\begin{array}{l}0.19 \text { to } \\
1.58\end{array}$ & $0.09^{\star}$ & $\begin{array}{l}0.01 \text { to } \\
0.71\end{array}$ & $0.02^{2 * *}$ & $\begin{array}{l}0.00 \text { to } \\
0.20\end{array}$ & $0.22^{* *}$ & $\begin{array}{l}0.08 \text { to } \\
0.61\end{array}$ & $0.06^{* *}$ & $\begin{array}{l}0.01 \text { to } \\
0.61\end{array}$ & 0.28 & $\begin{array}{l}0.03 \text { to } \\
2.54\end{array}$ & (omitted) $\dagger$ & & 0.11 & $\begin{array}{l}0.01 \text { to } \\
1.11\end{array}$ & (omitted) $\dagger$ & \\
\hline Primary & $0.53^{* * *}$ & $\begin{array}{l}0.36 \text { to } \\
0.78\end{array}$ & 0.67 & $\begin{array}{l}0.43 \text { to } \\
1.03\end{array}$ & $0.54^{* \star}$ & $0.34,0.86$ & 0.65 & $\begin{array}{l}0.37 \text { to } \\
1.13\end{array}$ & 0.65 & $\begin{array}{l}0.42 \text { to } \\
1.02\end{array}$ & $0.47^{\star \star}$ & $\begin{array}{l}0.29 \text { to } \\
0.78\end{array}$ & $0.53^{\star \star}$ & $\begin{array}{l}0.33 \text { to } \\
0.86\end{array}$ & $0.41^{\star \star \star}$ & $\begin{array}{l}0.23 \text { to } \\
0.71\end{array}$ & $0.36^{\star \star \star}$ & $\begin{array}{l}0.23 \text { to } \\
0.55\end{array}$ & $0.30^{* * *}$ & $\begin{array}{l}0.19 \text { to } \\
0.42\end{array}$ & $0.55^{*}$ & $\begin{array}{l}0.34 \text { to } \\
0.87\end{array}$ & $0.50^{\star \star}$ & $\begin{array}{l}0.30 \text { to } \\
0.83\end{array}$ \\
\hline Secondary & 0.74 & $\begin{array}{l}0.52 \text { to } \\
1.05\end{array}$ & 0.75 & $\begin{array}{l}0.52 \text { to } \\
1.09\end{array}$ & 0.68 & $\begin{array}{l}0.45 \text { to } \\
1.02\end{array}$ & 0.75 & $\begin{array}{l}0.45 \text { to } \\
1.24\end{array}$ & 0.74 & $\begin{array}{l}0.50 \text { to } \\
1.11\end{array}$ & 0.78 & $\begin{array}{l}0.51 \text { to } \\
1.19\end{array}$ & 0.66 & $\begin{array}{l}0.43 \text { to } \\
1.04\end{array}$ & 0.66 & $\begin{array}{l}0.40 \text { to } \\
1.07\end{array}$ & $0.58^{* *}$ & $\begin{array}{l}0.41 \text { to } \\
0.83\end{array}$ & $0.46^{\star \star \star}$ & $\begin{array}{l}0.32 \text { to } \\
0.65\end{array}$ & 0.72 & $\begin{array}{l}0.50 \text { to } \\
1.04\end{array}$ & 0.85 & $\begin{array}{l}0.57 \text { to } \\
1.27\end{array}$ \\
\hline $\begin{array}{l}\text { Higher } \\
\text { (reference) }\end{array}$ & 1.00 & & 1.00 & & 1.00 & & 1.00 & & 1.00 & & 1.00 & & 1.00 & & 1.00 & & 1.00 & & 1.00 & & 1.00 & & 1.00 & \\
\hline $\begin{array}{l}\text { Woman's age } \\
<20\end{array}$ & 0.91 & $\begin{array}{l}1.02 \text { to } \\
1.62\end{array}$ & $0.45^{* *}$ & $\begin{array}{l}0.27 \text { to } \\
0.74\end{array}$ & 1.12 & $\begin{array}{l}0.66 \text { to } \\
1.90\end{array}$ & 0.91 & $\begin{array}{l}0.52 \text { to } \\
1.58\end{array}$ & 0.93 & $\begin{array}{l}0.54 \text { to } \\
1.61\end{array}$ & 0.70 & $\begin{array}{l}0.39 \text { to } \\
1.26\end{array}$ & 0.89 & $\begin{array}{l}0.52 \text { to } \\
1.53\end{array}$ & 0.92 & $\begin{array}{l}0.51 \text { to } \\
1.66\end{array}$ & 0.88 & $\begin{array}{l}0.46 \text { to } \\
1.71\end{array}$ & 0.73 & $\begin{array}{l}0.34 \text { to } \\
1.57\end{array}$ & 0.70 & $\begin{array}{l}0.41 \text { to } \\
1.20\end{array}$ & 0.74 & $\begin{array}{l}0.42 \text { to } \\
1.31\end{array}$ \\
\hline $\begin{array}{l}20-29 \\
\text { (reference) }\end{array}$ & 1.00 & & 1.00 & & 1.00 & & 1.00 & & 1.00 & & 1.00 & & 1.00 & & 1.00 & & 1.00 & & 1.00 & & 1.00 & & 1.00 & \\
\hline $30-39$ & 1.29 & $\begin{array}{l}0.98 \text { to } \\
1.69\end{array}$ & $1.86^{* \star \star}$ & $\begin{array}{l}1.34 \text { to } \\
2.58\end{array}$ & 1.20 & $\begin{array}{l}0.86 \text { to } \\
1.66\end{array}$ & 1.42 & $\begin{array}{l}0.98 \text { to } \\
2.04\end{array}$ & 1.17 & $\begin{array}{l}0.86 \text { to } \\
1.60\end{array}$ & $1.59^{* *}$ & $\begin{array}{l}1.10 \text { to } \\
2.29\end{array}$ & 1.31 & $\begin{array}{l}0.92 \text { to } \\
1.89\end{array}$ & $1.54^{* *}$ & $\begin{array}{l}1.03 \text { to } \\
2.30\end{array}$ & 1.36 & $\begin{array}{l}0.98 \text { to } \\
1.91\end{array}$ & 1.26 & $\begin{array}{l}0.85 \text { to } \\
1.85\end{array}$ & $1.46^{* *}$ & $\begin{array}{l}1.03 \text { to } \\
2.07\end{array}$ & $1.59^{* *}$ & $\begin{array}{l}1.05 \text { to } \\
2.40\end{array}$ \\
\hline$\geq 40$ & 1.41 & $\begin{array}{l}0.84 \text { to } \\
2.39\end{array}$ & 1.66 & $\begin{array}{l}0.94 \text { to } \\
2.91\end{array}$ & 0.87 & $\begin{array}{l}0.46 \text { to } \\
1.62\end{array}$ & 0.92 & $\begin{array}{l}0.49 \text { to } \\
1.70\end{array}$ & $1.96^{*}$ & $\begin{array}{l}1.07 \text { to } \\
3.57\end{array}$ & 1.56 & $\begin{array}{l}0.81 \text { to } \\
2.99\end{array}$ & 0.87 & $\begin{array}{l}0.42 \text { to } \\
1.83\end{array}$ & $3.12^{* *}$ & $\begin{array}{l}1.48 \text { to } \\
6.58\end{array}$ & 1.96 & $\begin{array}{l}0.97 \text { to } \\
3.97\end{array}$ & 2.02 & $\begin{array}{l}0.98 \text { to } \\
4.15\end{array}$ & 1.04 & $\begin{array}{l}0.47 \text { to } \\
2.32\end{array}$ & $3.44^{\star \star \star}$ & $\begin{array}{l}1.69 \text { to } \\
6.98\end{array}$ \\
\hline $\begin{array}{l}\text { Birth order } \\
\quad 1 \\
\text { (reference) }\end{array}$ & 1.00 & & 1.00 & & 1.00 & & 1.00 & & 1.00 & & 1.00 & & 1.00 & & 1.00 & & 1.00 & & 1.00 & & 1.00 & & 1.00 & \\
\hline 2 & 0.76 & $\begin{array}{l}0.55 \text { to } \\
1.06\end{array}$ & 0.88 & $\begin{array}{l}0.60 \text { to } \\
1.30\end{array}$ & 0.84 & $\begin{array}{l}0.57 \text { to } \\
1.25\end{array}$ & 0.79 & $\begin{array}{l}0.50 \text { to } \\
1.27\end{array}$ & 0.76 & $\begin{array}{l}0.53 \text { to } \\
1.11\end{array}$ & $0.61^{* *}$ & $\begin{array}{l}0.40 \text { to } \\
0.93\end{array}$ & 0.76 & $\begin{array}{l}0.49 \text { to } \\
1.17\end{array}$ & 0.87 & $\begin{array}{l}0.57 \text { to } \\
1.33\end{array}$ & $0.53^{\star \star \star}$ & $\begin{array}{l}0.35 \text { to } \\
0.78\end{array}$ & $0.52^{\star \star}$ & $\begin{array}{l}0.33 \text { to } \\
0.80\end{array}$ & $0.50^{\star \star \star}$ & $\begin{array}{l}0.34 \text { to } \\
0.74\end{array}$ & $0.56^{* *}$ & $\begin{array}{l}0.37 \text { to } \\
0.84\end{array}$ \\
\hline 3 & $0.64^{*}$ & $\begin{array}{l}0.45 \text { to } \\
0.93\end{array}$ & $0.64^{*}$ & $\begin{array}{l}0.42 \text { to } \\
0.97\end{array}$ & 0.92 & $\begin{array}{l}0.59 \text { to } \\
1.45\end{array}$ & $0.55^{\star *}$ & $\begin{array}{l}0.33 \text { to } \\
0.92\end{array}$ & $0.50^{\star \star \star}$ & $\begin{array}{l}0.33 \text { to } \\
0.76\end{array}$ & 0.75 & $\begin{array}{l}0.47 \text { to } \\
1.18\end{array}$ & 0.69 & $\begin{array}{l}0.42 \text { to } \\
1.13\end{array}$ & 0.61 & $\begin{array}{l}0.36 \text { to } \\
1.02\end{array}$ & $0.36^{\star \star \star}$ & $\begin{array}{l}0.23 \text { to } \\
0.55\end{array}$ & 0.72 & $\begin{array}{l}0.44 \text { to } \\
1.16\end{array}$ & $0.45^{\star \star \star}$ & $\begin{array}{l}0.29 \text { to } \\
0.70\end{array}$ & $0.37^{\star \star \star}$ & $\begin{array}{l}0.23 \text { to } \\
0.61\end{array}$ \\
\hline$\geq 4$ & $0.41^{* * *}$ & $\begin{array}{l}0.30 \text { to } \\
0.58\end{array}$ & $0.36^{* * *}$ & $\begin{array}{l}0.24 \text { to } \\
0.54\end{array}$ & $0.56^{* *}$ & $\begin{array}{l}0.36 \text { to } \\
0.87\end{array}$ & $0.53^{\star \star}$ & $\begin{array}{l}0.32 \text { to } \\
0.88\end{array}$ & $0.47^{* \star \star}$ & $\begin{array}{l}0.32 \text { to } \\
0.69\end{array}$ & $0.31^{\star * \star}$ & $\begin{array}{l}0.20 \text { to } \\
0.49\end{array}$ & $0.51^{* *}$ & $\begin{array}{l}0.31 \text { to } \\
0.82\end{array}$ & $0.47^{\star \star}$ & $\begin{array}{l}0.28 \text { to } \\
0.80\end{array}$ & $0.32^{\star \star \star}$ & $\begin{array}{l}0.21 \text { to } \\
0.49\end{array}$ & $0.41^{\star \star \star}$ & $\begin{array}{l}0.25 \text { to } \\
0.67\end{array}$ & $0.28^{\star \star \star}$ & $\begin{array}{l}0.18 \text { to } \\
0.45\end{array}$ & $0.23^{\star \star \star}$ & $\begin{array}{l}0.13 \text { to } \\
0.38\end{array}$ \\
\hline Wealth index & & & & & & & & & & & & & & & & & & & & & & & & \\
\hline $\begin{array}{l}\text { Lowest } \\
\text { (reference) }\end{array}$ & 1.00 & & 1.00 & & 1.00 & & 1.00 & & 1.00 & & 1.00 & & 1.00 & & 1.00 & & 1.00 & & 1.00 & & 1.00 & & 1.00 & \\
\hline Second & 1.09 & $\begin{array}{l}0.79 \text { to } \\
1.50\end{array}$ & 1.21 & $\begin{array}{l}0.86 \text { to } \\
1.70\end{array}$ & 0.85 & $\begin{array}{l}0.59 \text { to } \\
1.24\end{array}$ & 1.48 & $\begin{array}{l}0.99 \text { to } \\
2.20\end{array}$ & $2.00^{\star \star \star}$ & $\begin{array}{l}1.38 \text { to } \\
2.89\end{array}$ & $1.99^{\star \star \star}$ & $\begin{array}{l}1.34 \text { to } \\
2.96\end{array}$ & $2.06^{\star \star \star}$ & $\begin{array}{l}1.36 \text { to } \\
3.13\end{array}$ & $1.74^{\star \star}$ & $\begin{array}{l}1.14 \text { to } \\
2.64\end{array}$ & $2.11^{\star *}$ & $\begin{array}{l}1.16 \text { to } \\
3.83\end{array}$ & $1.88^{*}$ & $\begin{array}{l}1.07 \text { to } \\
3.29\end{array}$ & $2.15^{\star \star}$ & $\begin{array}{l}1.25 \text { to } \\
3.71\end{array}$ & $1.79^{\star \star}$ & $\begin{array}{l}1.05 \text { to } \\
3.05\end{array}$ \\
\hline Middle & 1.26 & $\begin{array}{l}0.89 \text { to } \\
1.78\end{array}$ & $1.85^{\star \star}$ & $\begin{array}{l}1.26 \text { to } \\
2.72\end{array}$ & 0.77 & $\begin{array}{l}0.51 \text { to } \\
1.16\end{array}$ & 1.25 & $\begin{array}{l}0.80 \text { to } \\
1.96\end{array}$ & $3.30^{\star \star \star}$ & $\begin{array}{l}2.26 \text { to } \\
4.83\end{array}$ & $4.05^{\star \star \star}$ & $\begin{array}{l}2.63 \text { to } \\
6.24\end{array}$ & $2.95^{\star \star \star}$ & $\begin{array}{l}1.88 \text { to } \\
4.64\end{array}$ & $3.43^{* \star *}$ & $\begin{array}{l}2.18 \text { to } \\
5.34\end{array}$ & $2.83^{\star \star \star}$ & $\begin{array}{l}1.58 \text { to } \\
5.07\end{array}$ & $2.31^{\star *}$ & $\begin{array}{l}1.29 \text { to } \\
4.14\end{array}$ & $3.01^{\star \star \star}$ & $\begin{array}{l}1.73 \text { to } \\
5.22\end{array}$ & $3.46^{\star \star \star}$ & $\begin{array}{l}2.02 \text { to } \\
5.91\end{array}$ \\
\hline Fourth & $1.68^{* \star}$ & 1.16 to & $2.25^{* \star *}$ & 1.45 to & 1.12 & 0.70 to & $2.06^{* *}$ & 1.19 to & $4.71^{\star \star \star *}$ & 3.11 to & $7.17^{* \star *}$ & 4.33 to & $4.87^{\star \star \star}$ & 2.90 to & $7.20^{* \star *}$ & $4.22,12.30$ & $4.50^{\star \star \star}$ & 2.50 to & $4.29^{* \star *}$ & 2.38 to & $4.07^{\star \star \star}$ & 2.32 to & $6.09^{* \star *}$ & 3.41 to \\
\hline Highest & $3.43^{* \star *}$ & $\begin{array}{l}2.43 \\
2.22 \text { to } \\
5.28\end{array}$ & $3.54^{\star \star \star}$ & $\begin{array}{l}3.52 \\
1.98 \text { to } \\
6.33\end{array}$ & $2.44^{\star \star}$ & $\begin{array}{l}1.81 \\
1.31 \text { to } \\
4.54\end{array}$ & $2.87^{* *}$ & $\begin{array}{l}3.57 \\
1.31 \text { to } \\
6.29\end{array}$ & $9.92^{* \star \star}$ & $\begin{array}{l}7.13 \\
5.98 \text { to } \\
16.43\end{array}$ & $12.29^{* \star \star}$ & $\begin{array}{l}11.86 \\
6.22 \text { to } \\
24.27\end{array}$ & $6.98^{\star \star \star}$ & $\begin{array}{l}8.19 \\
3.62 \text { to } \\
13.46\end{array}$ & $15.53^{\star \star \star}$ & $\begin{array}{l}6.90 \text { to } \\
34.94\end{array}$ & $7.74^{* \star \star}$ & $\begin{array}{l}8.13 \\
4.22 \text { to } \\
14.21\end{array}$ & $7.55^{* \star *}$ & $\begin{array}{l}7.74 \\
3.95 \text { to } \\
14.44\end{array}$ & $6.98^{* \star \star}$ & $\begin{array}{l}7.13 \\
3.76 \text { to } \\
12.94\end{array}$ & $16.00^{\star \star \star *}$ & $\begin{array}{l}10.89 \\
7.99 \text { to } \\
32.02\end{array}$ \\
\hline
\end{tabular}


Part A. Woman's education

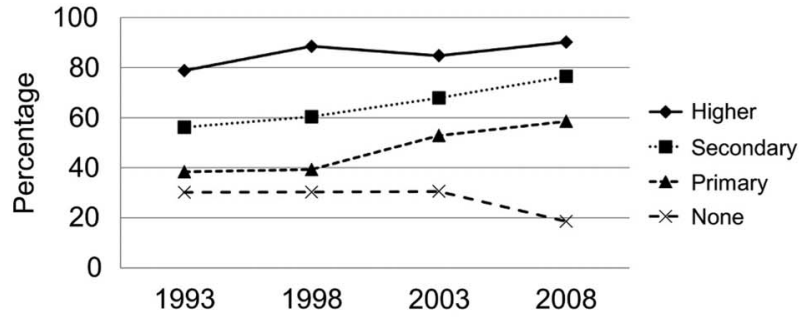

Part B. Partner's education

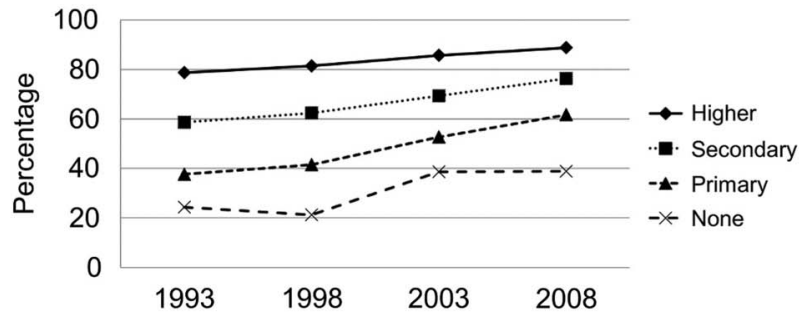

Part C. Wealth Index

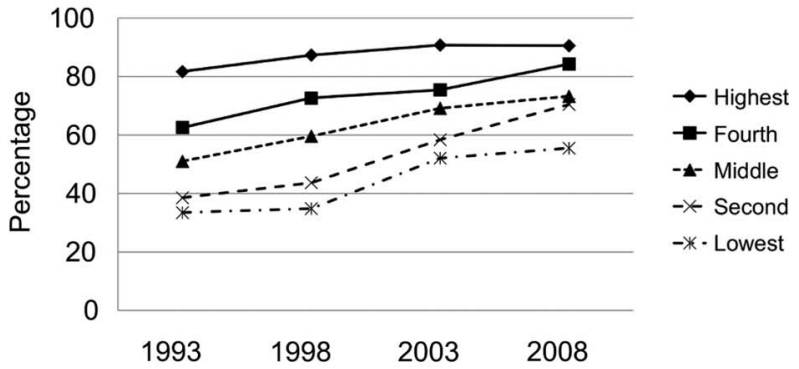

Figure 2 Trends in the percentage of antenatal-care use by (A) woman's education, (B) partner's education, (C) wealth index, 1993-2008. Note: Concentration index based on wealth index in $1993(0.19,95 \% \mathrm{Cl} 0.16$ to 0.21$) ; 1998(0.18$, $95 \% \mathrm{Cl} 0.16$ to 0.21$) ; 2003(0.12,95 \% \mathrm{Cl} 0.09$ to 0.14$)$; and $2008(0.09,95 \% \mathrm{Cl} 0.07$ to 0.11$)$.

the highest quintile compared with those in the lowest quintile, with a difference of $48.2 \%$ point in 1993 decreasing to $35.0 \%$ point in 2008. A reduction in the concentration index for ANC was observed from 1993 to 2008.

Figure 3 shows the limited changes in the inequality of SBA from 1993 to 2008. A reduction was observed in the gradient of SBA in comparison between women with no education and those with higher education with a difference of $76.6 \%$ point in 1993 decreasing to $70.7 \%$ point in 2008. In contrast, women in the highest quintile compared with those in the lowest quintile increased from a difference of $69.1 \%$ point in 1993 increasing to $71.1 \%$ point in 2008. A reduction in the concentration index for SBA was observed from 1993 to 2008; however, the concentration index obtained was larger than that for ANC.

Figure 4 shows the changes in inequality of MEDFAC from 1993 to 2008. As shown in the figure, the gradient of MEDFAC between women with no education and those
Part A. Woman's education

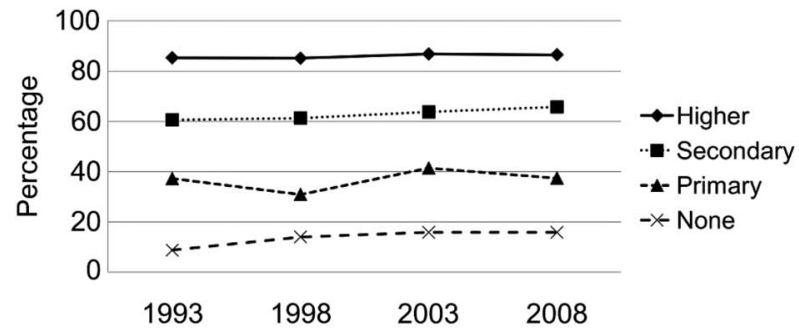

Part B. Partner's education

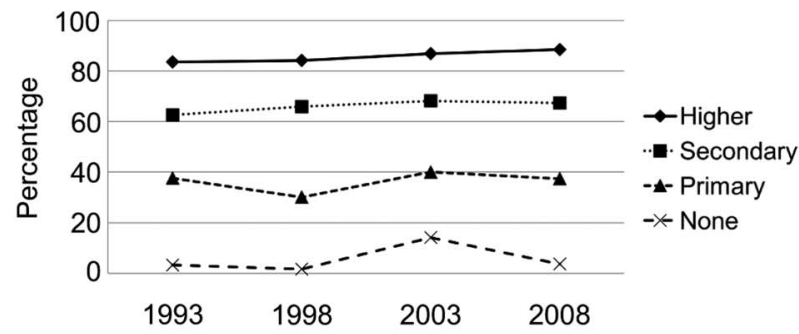

Part C. Wealth Index

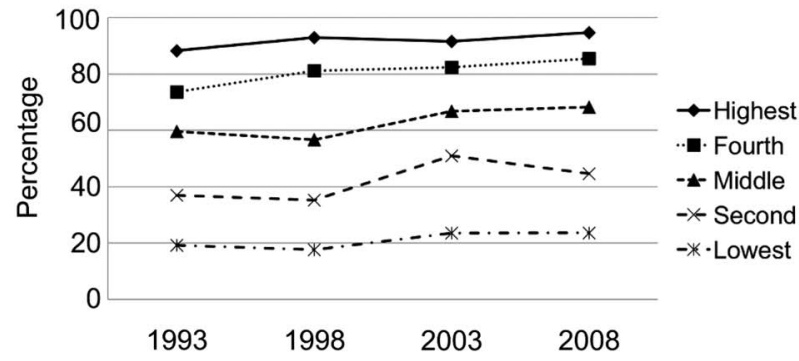

Figure 3 Trends in the percentage of skilled birth attendance by $(A)$ woman's education, $(B)$ partner's education, (C) wealth index, 1993-2008. Note: Concentration index based on wealth index in $1993(0.26,95 \% \mathrm{Cl} 0.24$ to $0.29) ; 1998(0.29,95 \% \mathrm{Cl} 0.26$ to 0.31$) ; 2003(0.22,95 \% \mathrm{Cl}$ 0.20 to 0.24$)$; and $2008(0.24,95 \% \mathrm{Cl} 0.21$ to 0.27$)$.

with higher education widened from a difference of $60.4 \%$ in 1993 to $67 \%$ in 2008. The difference between MEDFAC $\%$ in the highest quintile and that in the poorest quintile increased from $59.5 \%$ point in 1993 to $75.6 \%$ point in 2008. A reduction in the concentration index for MEDFAC was observed from 1993 to 2008; however, the concentration index obtained was also large in comparison with ANC.

\section{DISCUSSION}

This is the first study to describe the time trends in the inequalities of maternal healthcare utilisation in the Philippines. The analysis of four nationally representative PDHS survey data sets ranged over a period of 16 years from 1993 to 2008 and showed a substantial increase in antenatal coverage and limited improvement in professional delivery care. Furthermore, our findings demonstrated a reduction in the inequality of ANC use through time, suggesting the coverage of women in the 
Part A. Woman's education

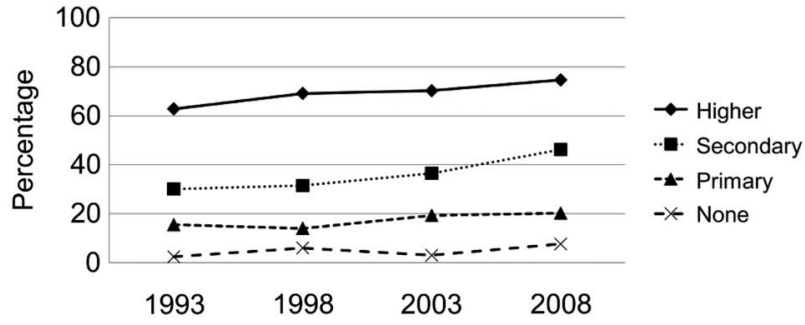

Part B. Partner's education

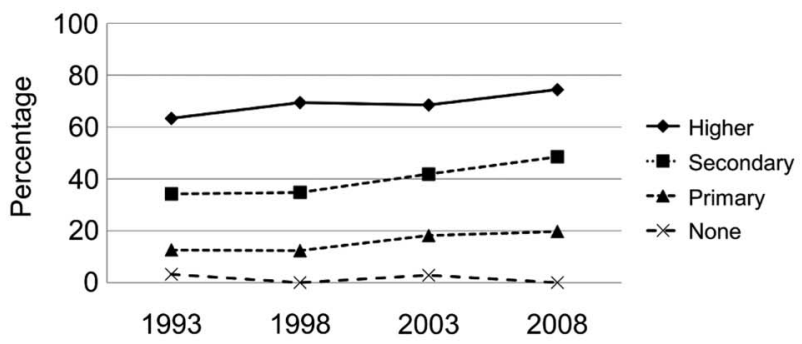

Part C. Wealth Index

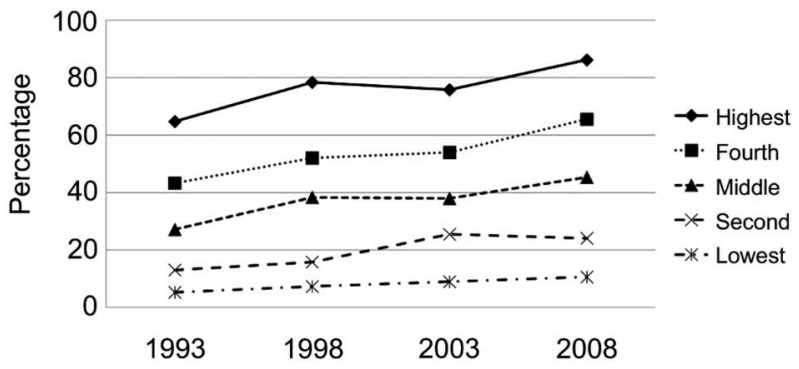

Figure 4 Trends in the percentage of delivery at medical facility by $(A)$ woman's education, $(B)$ partner's education, (C) wealth index, 1993-2008. Note: Concentration index based on wealth index in $1993(0.41,95 \% \mathrm{Cl} 0.38$ to 0.45$)$; 1998 (0.41, 95\% Cl 0.38 to 0.44$) ; 2003(0.34,95 \% \mathrm{Cl} 0.31$ to $0.37)$; and $2008(0.35,95 \% \mathrm{Cl} 0.32$ to 0.38$)$.

lowest quintile or possibly a decreased coverage for the wealthier quintile. The study also provided evidence of persistence of inequality in SBA and MEDFAC indicating minimal professional delivery care among women with the lowest socioeconomic conditions.

Our findings are in line with evidence on 25 lowincome countries' referred inequalities on institutional delivery rates as well as a weak health system and lack of skilled birth workers as the main barriers of use. ${ }^{21}$ Marked underutilisation of SBA has been noted among poor women in many studies. ${ }^{22}{ }^{23}$ However, one study conducted in India reported low utilisation of both ANC and SBA among poor women through time despite governmental interventions. ${ }^{24}$

The increase in proportion of antenatal coverage from 1993 to 2008 was greater than that of births attended by skilled health personnel or that of delivery at MEDFAC. Over the last several decades, the Philippine government has launched maternal health projects and programmes to improve women's health. These were implemented alongside extensive health system reforms across the country on health financing, health regulation, health service delivery and good governance in health following the decentralisation of healthcare services. ${ }^{25} \mathrm{~A}$ study indicated that implementation areas that have intensively adopted the health system-wide reforms have improved the overall maternal health outcomes compared with those that have not adopted them. However, the poorly developed health information systems and lack of referral emergency-care facilities in remote coastal and isolated mountain communities were the challenges that remained to be addressed. ${ }^{26}$

The results of the present study indicated reductions in the inequality of ANC use. This translates to substantial ANC use among women at the lowest living standard quintile. This can be explained by improvements in both the healthcare system and in the sociodemographic profile of the population. The PhilHealth has been reported to increase the uptake and standards of ANC. ${ }^{27}$ Improvements in the quality of services in healthcare institutions through accreditation and the coverage of financial costs by insurance contributed to the increased use of ANC by Filipino women regardless of the sociodemographic status. ${ }^{27} 28$ There was also an increase in the total number of midwives and rural (barangay) health units over the years, which addressed the problems of distance and lack of availability of health workers and ANC facilities. ${ }^{29}$ Moreover, positive changes in the sociodemographic and demographic profiles, such as increases in the educational status of women and their partners, better economic status of women and decreased fertility, may also explain the observed reductions in the inequality of ANC use. ${ }^{30}$

Inequalities in SBA and MEDFAC persist in the Philippines despite the health system-wide efforts and improvements in the sociodemographic profile of the population. After 16 years, the majority of Filipino women from the lowest living standard quintile continue to deliver at home without professional assistance. In the Philippines, finance, transportation, absence of companion to accompany to the health facility and treatment of health professionals to disadvantaged women are major barriers that must be addressed to increase the rate of hospital delivery. ${ }^{31}$ The majority of unskilled home deliveries among Filipino women occur near hospitals, and financial burden associated with hospital delivery is the main concern regardless of socioeconomic status. In 2009, for families from the lowest $30 \%$ income group, delivery at a hospital would consume a minimum of $6.6-24.3 \%$ of the family's total annual income. ${ }^{32} 33$ This indicates that catastrophic financial costs are responsible for the decision by poorer Filipino women to deliver at home, even if they are close to health facilities, in addition to loweducational status and rural residence. PhilHealth coverage is low with only $42 \%$ of families with at least one family member being enrolled in 2004. ${ }^{34}$ Furthermore, the out-of-pocket expenditure as a 
percentage of private expenditure on health has increased from $77.2 \%$ in 2000 to $83.6 \%$ in $2010 .^{35}$

This study has a number of strengths. It used four nationally representative samples obtained by the DHS and commonly used as data sources in the literature worldwide. A national sample of women aged 15-49 years were collected to obtain a sufficient sample size for each survey year. Selection of the women who had live-births only within 1 year as the participants of the individual surveys sharpened the comparison of the data of four different years. This reduced the magnitude of recall bias by the respondents. All four PDHS followed strict data quality checks through pretesting, translation of questionnaires into the local dialect, interviewer training and duplicate data entry. It also employed a standardised questionnaire format which was carefully developed to ascertain accurate responses and information from the participants. The analysis used the DHS-wealth index, a systematically developed composite index, to measure the economic status of the participants among the DHS samples. The study used relevant measurements of inequity, the concentration index, which measures the long-term trends in inequalities in the utilisation of critical maternal healthcare interventions in the Philippines, which is important for future health policy.

Caution should be exercised in interpreting trends of maternal healthcare use by the DHS-wealth index since it is an index to show the relative position measured by a composite economic-status indicator among the participants of the particular year and country. Therefore, the scores of wealth index in different years are not comparable.

Our study implies the need for research solutions to reduce inequality in SBA and delivery at MEDFAC, and to determine the factors responsible for the persistence of inequality in SBA and delivery at MEDFAC despite government and non-governmental efforts. Recognising reproductive health as a basic right of women regardless of sociodemographic status is important in formulating national policy and programmes to address inequality in maternal health service utilisation.

Acknowledgements We are thankful to MEASURE DHS for allowing us to analyse the 1993, 1998, 2003 and 2008 PDHS data sets. We also acknowledge with the deepest thankfulness the organisations and individuals in the Philippines who contributed to the 1993, 1998, 2003 and 2008 PDHS.

Contributors FM and KN conceptualised and designed the study. FM obtained the data and FM and MK analysed the data. FM, KN, MK and SK structured and edited the manuscript. All authors approved the final manuscript.

Funding This research received no specific grant from any funding agency in the public, commercial or not-for-profit sectors.

Competing interests None.

Provenance and peer review Not commissioned; externally peer reviewed.

Data sharing statement No additional data are available.

\section{REFERENCES}

1. Commission on information and accountability for Women's and Children's Health. Keeping promises, measuring results. World Health Organization, 2011. http://www.everywomaneverychild.org/ images/content/files/accountability_commission/final_report/ Final_EN_Web.pdf (accessed Mar 2012).

2. Thomsen $\mathrm{S}$, Hoa DT, Målqvist $\mathrm{M}$, et al. Promoting equity to achieve maternal and child health. Reprod Health Matters 2011;19:176-82.

3. Barros $\mathrm{AJ}$, Ronsmans $\mathrm{C}$, Axelson $\mathrm{H}$, et al. Equity in maternal, newborn and child health interventions in countdown to 2015: a retrospective review of survey data from 54 countries. Lancet 2012;379:1225-33.

4. Zere E, Kirigia JM, Duale S, et al. Inequities in maternal and child health outcomes and interventions in Ghana. BMC Public Health 2012;12:252.

5. Wirth M, Sacks E, Delamonica E, et al. "Delivering on the mdgs?": equity and maternal health in Ghana, Ethiopia and Kenya. East Afr $J$ Public Health 2008;5:133-41.

6. Silal SP, Penn Kenana L, Harris B, et al. Exploring inequalities in access to and use of maternal health services in South Africa. BMC Health Serv Res 2012;12:120.

7. Asian Development Bank Operations Evaluation Department. Project performance evaluation report in the Philippines. Asian Development Bank, 2007. http://www.adb.org/sites/default/files/27010-PHI-PPER. pdf (accessed Jan 2013).

8. WHO, UNICEF, UNFPA, The World Bank. Trends in maternal mortality 1990-2010: WHO, UNICEF, UNFPA and The World Bank estimates. Geneva: World Health Organization, 2012. http://www. unfpa.org/webdav/site/global/shared/documents/publications/2012/ Trends_in_maternal_mortality_A4-1.pdf (accessed Mar 2012).

9. Lavado RF, Lagrada LP. Are Maternal and Child Care Programs Reaching the Poorest Regions in the Philippines? Philippine Institute for Developmental Studies. 2008 Nov; Discussion Paper Series No. 2008-30.

10. Demographic and Health Surveys. Calverton: Macro International. http://www.measuredhs.com/ (accessed Jul 2011).

11. Rutstein SO, Rojas G. Guide to DHS statistics. Calverton, MD: ORC Macro International, 2003.

12. Croft T. DHS Data editing and imputation. Calverton, MD: ORC Macro International, 2008.

13. National Statistics Office (NSO) [Philippines] and Macro International Inc. (MI). National Demographic Survey 1993. Calverton, MD: NSO and MI, 1994.

14. National Statistics Office (NSO), Department of Health (DOH) [Philippines] and Macro International Inc. (MI). National Demographic Survey 1998. Manila: NSO and MI, 1999.

15. National Statistics Office (NSO) [Philippines], and ORC Macro. National Demographic Survey 2003. Calverton, Maryland: NSO and ORC Macro, 2004.

16. National Statistics Office (NSO) [Philippines], and ICF Macro. National Demographic Survey 2008. Calverton, MD: National Statistics Office and ICF Macro, 2009.

17. Rutstein SO, Kiersten J. The DHS wealth index. DHS comparative reports No. 6. Calverton, MD: ORC Macro International, 2004.

18. ICF International. Survey Organization Manual for Demographic and Health Surveys. MEASURE DHS. Calverton. Maryland: ICF International 2012. http://www.measuredhs.com/pubs/pdf/DHSM10/ DHS6_Survey_Org_Manual_28Feb2012.pdf (accessed July 2012).

19. O'Donnell O, Van Doorslaer E, Wagstaff A, et al. Analyzing health equity using household survey data: a guide to techniques and their implementation. Washington, DC: The World Bank, 2008. http:// siteresources.worldbank.org/INTPAH/Resources/Publications/ 459843-1195594469249/HealthEquityFINAL.pdf (accessed Jul 2011).

20. Wagstaff $A$. The concentration index of a binary outcome revisited. $J$ Health Econ 2011;20:1155-60.

21. Limwattananon S, Tangcharoensathien V, Sirilak S. Trends and inequities in where women delivered their babies in 25 low-income countries: evidence from Demographic and Health Surveys. Reprod Health Matters 2011;19:75-85.

22. Zere E, Oluwole D, Kirigia JM, et al. Inequalities in skilled attendance at birth in Namibia: a decomposition analysis. BMC Pregnancy Childbirth 2011;11:34.

23. Collin SM, Anwar I, Ronsmans C. A decade of inequality in maternity care: antenatal care, professional attendance at delivery, and caesarean section in Bangladesh (1991-2004). Int J Equity Health 2007;6:9.

24. Pathak PK, Singh A, Subramanian SV. Economic Inequalities in maternal health care: prenatal care and skilled birth attendance in India, 1992-2006. PLOS ONE 2010;5:e13593.

25. Lakshminarayanan R. Decentralisation and its implications for reproductive health: the Philippines experience. Reprod Health Matters 2003;11:96-107.

26. Huntington D, Banzon E, Recidoro ZD. A systems approach to improving maternal health in the Philippines. Bull World Health Organ 2012;90:104-10. 
27. Kozhimannil KB, Valera MR, Adams A, et al. The population-level impacts of a national health insurance program and franchise midwife clinics on achievement of prenatal and delivery care standards in the Philippines. Health Policy 2009;92:55-64.

28. Quimbo SA, Peabody JW, Shimkhada R, et al. Should we have confidence if a physician is accredited? A study of the relative impacts of accreditation and insurance payments on quality of care in the Philippines. Soc Sci Med 2008;67:505-10.

29. Department of Health. Vital, health and nutrition. Manila: National Statistical Coordination Board, 2012. http://www.nscb.gov.ph/secstat/ d_vital.asp (accessed Mar 2012).

30. Simkhada B, Teijlingen ER, Porter M, et al. Factors affecting the utilization of antenatal in developing countries: a systematic review of the literature. J Adv Nurs 2008;61:244-60.

31. Sobel HL, Oliveros YE, Nyunt US. Secondary analysis of a national health surveu on factoes influencing women in the Philippines to deliver at home and unattended by a healthcare professional. Int J Gynaecol Obstet 2010;111:157-60.
32. National Statistics Office. 2004 Annual Poverty Indicators Survey (APIS) (Preliminary Results). Manila: National Statistics Office, 2005. http://www.census.gov.ph/content/2004-annual-poverty-indicatorssurvey-apis-preliminary-results (accessed Jan 2013).

33. Ericta CN. Families in the bottom 30 percent income group earned 62 thousand pesos in 2009. Manila: National Statistics Office, 2011. http://www.census.gov.ph/data/pressrelease/2011/ie09frtx.html (accessed Mar 2012).

34. Tsolmongerel T. Costing study for selected hospitals in the Philippines. 2009. http://www.doh.gov.ph/sites/default/files/Costing\% 20Study\%2Ofor\%20Selected\%20Hospitals\%20in\%20the\% 20Philippines.pdf (accessed Mar 2012).

35. Global Health expenditure Database. Philippines national expenditure on health (Philippine Peso) 1995-2010. World Health Organization, 2012. http://apps.who.int/nha/database/ StandardReport.aspx?ID=REP_WEB_MINI_TEMPLATE_WEB_ VERSION\&COUNTRYKEY $=84655$ 